\title{
Socio-climatic hotspots in Brazil
}

\author{
Roger R. Torres • David M. Lapola • Jose A. Marengo • Magda A. Lombardo
}

Received: 16 September 2011 / Accepted: 23 March 2012

(C) Springer Science+Business Media B.V. 2012

\begin{abstract}
Brazil suffers yearly from extreme weather and climate events, which can be exacerbated in a warmer climate. Although several studies have analyzed the projections of climate change in Brazil, little attention has been paid to defining the locations that can be most affected, and consequently have a more vulnerable population, in a spatially-explicit form. This study presents a spatial analysis of summarized climate change data and a joint investigation combining these possible climate changes and social vulnerability indicators in Brazil. The Regional Climate Change Index $(R C C I)$, which can synthesize a large number of climate model projections, is used for the climate analysis, and the Socio-Climatic Vulnerability Index $(S C V I)$ is proposed to aggregate local population vulnerabilities to the climate change information. The RCCI results show climatic hotspots emerging in Brazil, covering the western portion of the Northeast (NE), northwestern Minas Gerais state and centerwestern $(\mathrm{CW})$ and northern regions $(\mathrm{N})$, except northeast Pará and Amapá states. The SCVI analysis reveals major socio-climatic hotspots in the NE and several localized hotspots in some of the major Brazilian metropolitan regions, namely Manaus, Belo Horizonte, Brasília,
\end{abstract}

R. R. Torres $(\bowtie)$

Center for Weather Forecast and Climate Studies (CPTEC), National Institute for Space Research (INPE),

Cachoeira Paulista, SP, Brazil

e-mail: roger.torres@cptec.inpe.br

D. M. Lapola

Earth System Science Lab (LabTerra), Departament of Ecology, São Paulo State University (UNESP), Rio Claro, SP, Brazil

\section{J. A. Marengo}

Center for Earth System Science, National Institute for Space Research (INPE), Cachoeira Paulista, SP, Brazil

M. A. Lombardo

Center for Environmental Planning and Analysis (CEAPLA), São Paulo State University (UNESP),

Rio Claro, SP, Brazil 
Salvador, Rio de Janeiro and São Paulo. The two novelties of this study are a spatially detailed analysis of the RCCI in Brazil and the development of an index that can summarize the large amount of climate model information available today with social vulnerability indicators. Both indices may be important tools for improving the dialogue between climate and social scientists and for communicating climate change to policymakers in a more synthetic and socially relevant form.

\section{Introduction}

Projections indicate a considerable change in Brazil's climate within this century (Baettig et al. 2007; Marengo et al. 2009, 2010a), and there are several reasons to believe Brazil will be highly impacted by such climatic change: its economy depends heavily on exports of agricultural commodities (IPEA 2011); the provision of staple foods is strongly reliant on smallholder agriculture (responsible, for example, for $87 \%$ of the national production of cassava, $70 \%$ of dry beans, $46 \%$ of maize, and $58 \%$ of milk) (IBGE 2009); it has an energy matrix dominated by renewable energy, which is highly susceptible to climate variations (Lucena et al. 2009); and it still suffers widespread poverty, significant social inequality and epidemic outbreaks (IPEA 2003; Magrin et al. 2007; Confalonieri et al. 2009). The floods in São Paulo city in the summer of 2010 (Folha de São Paulo 2010), the landslides in the state of Rio de Janeiro in the summer of 2011 (Folha de São Paulo 2011), the annual dengue fever epidemics throughout the entire country, and the succession of intense droughts and floods events in Amazonia and Northeast (NE) Brazil (Marengo et al. 2011c, d; Ponce 1995) reveal how unprepared Brazil is for climate change.

Several studies have examined the effects of climate change in Brazil using different general circulation models (GCMs) and dynamical downscaling methods (e.g., Vera et al. 2006; Bombardi and Carvalho 2009; Marengo et al. 2010a, b, 2011a; Rusticucci et al. 2010). Despite the contribution of these studies to our knowledge of climate change, uncertainties about the regional climate impacts still remain. Moreover, the intrinsic uncertainties of climate change projections (Giorgi 2005; Knutti 2008) make the interactions between climate scientists and social scientists and, importantly, between scientists and policymakers, very difficult (Pidgeon and Fischhoff 2011). One possibility to improve the communication between climate scientists and others is the creation of climate change indices that aggregate various information and measures of uncertainty concisely and reliably (Giorgi 2006; Baettig et al. 2007; Xu et al. 2009). However, there is currently no scientific study showing where climate change hotspots (the word "hotspots" is used in this study to indicate areas with large regional climate changes and/or a highly vulnerable population) are located in Brazil and how these climate hotspots relate to population density and social conditions, such as poverty, education and health, in a country-wide perspective.

Therefore, this study addresses the need for straightforward and synthesized assessments of climate change and its probable social impacts in Brazil by presenting a spatially explicit analysis of Brazil's socio-climatic hotspots by relating more than one hundred climate projections with indicators of social vulnerability to climate change. The Regional Climate Change Index (RCCI) developed by Giorgi (2006) is applied specifically to Brazil and is incremented with social vulnerability proxies to compose what is defined here as the Socio-Climatic Vulnerability Index $(S C V I)$. The SCVI is a timely approach to identifying the areas for which climate change projections have the most human/social relevance. This information can then be used to target areas where actions towards adaptation should be prioritized. 


\section{Methods}

\subsection{Climate simulation dataset}

This study uses monthly precipitation and surface air temperature data simulated for the present climate (1961-1990) and projected to the end of this century (2071-2100) from 24 GCMs of the Coupled Model Inter-comparison Project Phase 3 (CMIP3) employed in the Intergovernmental Panel on Climate Change (IPCC) Fourth Assessment Report (IPCC 2007) (Table 1). Hereafter, the word change(s) refers to the difference between the mean values of the climate variables for the periods 2071-2100 and 1961-1990. Three sets of IPCC emission scenarios were used for the future period: SRES B1, A1B and A2, corresponding to equivalent $\mathrm{CO}_{2}$ concentrations of approximately 550, 700 and $850 \mathrm{ppm}$, respectively, in the year 2100 (Nakicenovic et al. 2000). The models and simulations are described in more detail in Meehl et al. (2007).

The GCMs spatial resolutions vary from roughly $1-5^{\circ}$ of latitude/longitude (Table 1 ). All GCMs were interpolated to a common $1^{\circ}$ grid, using the conservative remapping scheme (Jones 1999; Giorgi and Bi 2005; Giorgi 2006; Xu et al. 2009), for inter-comparison

Table 1 List of models, approximate model spatial resolutions, emissions scenarios and number of runs in the CMIP3 dataset used in this study. Models are ranked by their spatial resolution

\begin{tabular}{llllll}
\hline Models & Resolution (lat/lon) & 20C3M & A2 & A1B & B1 \\
\hline INM-CM3.0 & $5^{\circ} \times 4^{\circ}$ & 1 & 1 & 1 & 1 \\
GISS-EH & $5^{\circ} \times 4^{\circ}$ & 5 & - & 3 & - \\
GISS-ER & $5^{\circ} \times 4^{\circ}$ & 9 & 1 & 2 & 1 \\
GISS-AOM & $4^{\circ} \times 3^{\circ}$ & 2 & - & 2 & 2 \\
CGCM3.1(T47) & $3.8^{\circ} \times 3.8^{\circ}$ & 5 & 5 & 5 & 5 \\
ECHO-G & $3.8^{\circ} \times 3.8^{\circ}$ & 5 & 3 & 3 & 3 \\
UKMO-HadCM3 & $3.8^{\circ} \times 2.5^{\circ}$ & 2 & 1 & 1 & 1 \\
IPSL-CM4 & $3.8^{\circ} \times 2.5^{\circ}$ & 1 & 1 & 1 & 1 \\
FGOALS-g1.0 & $2.8^{\circ} \times 3^{\circ}$ & 3 & - & 2 & 3 \\
MRI-CGCM2.3.2 & $2.8^{\circ} \times 2.8^{\circ}$ & 5 & 5 & 5 & 5 \\
CGCM3.1(T63) & $2.8^{\circ} \times 2.8^{\circ}$ & 1 & - & 1 & 1 \\
CNRM-CM3 & $2.8^{\circ} \times 2.8^{\circ}$ & 1 & 1 & 1 & 1 \\
MIROC3.2(medres) & $2.8^{\circ} \times 2.8^{\circ}$ & 2 & 3 & 3 & 3 \\
PCM & $2.8^{\circ} \times 2.8^{\circ}$ & 4 & 4 & 4 & 2 \\
GFDL-CM2.0 & $2.5^{\circ} \times 2^{\circ}$ & 3 & 1 & 1 & 1 \\
GFDL-CM2.1 & $2.5^{\circ} \times 2^{\circ}$ & 3 & 1 & 1 & 1 \\
BCCR-BCM2.0 & $1.9^{\circ} \times 1.9^{\circ}$ & 1 & 1 & 1 & 1 \\
CSIRO-MK3.0 & $1.9^{\circ} \times 1.9^{\circ}$ & 3 & 1 & 1 & 1 \\
CSIRO-MK3.5 & $1.9^{\circ} \times 1.9^{\circ}$ & 3 & 1 & 1 & 1 \\
ECHAM5 & $1.9^{\circ} \times 1.9^{\circ}$ & 4 & 3 & 4 & 3 \\
UKMO-HadGEM1 & $1.9^{\circ} \times 1.3^{\circ}$ & 2 & 1 & 1 & - \\
CCSM3 & $1.4^{\circ} \times 1.4^{\circ}$ & 7 & 1 & 1 & 9 \\
ECHAM4 & $1.1^{\circ} \times 1.1^{\circ}$ & $1.1^{\circ} \times 1.1^{\circ}$ & 1 & 1 & - \\
MIROC3.2(hires) & & & & 1 & 1 \\
\hline
\end{tabular}


purposes and to properly relate them with social datasets in a reasonable grid size. However, one might argue that the interpolation of models from the coarsest to the highest resolution in an ensemble is not ideal. An appropriate technique to downscale the results of climate models would be statistical downscaling or dynamical downscaling (Boulanger et al. 2006; Christensen et al. 2007). Nevertheless, these two techniques are too time-consuming and/or computationally expensive and their application is highly non-trivial. Because this study aims to present a new approach to combine climate and social information, a more suitable interpolation or downscaling technique for the climate change dataset can be applied in future studies.

For the $R C C I$ calculation described in Section 2.2, all climate variables and statistics were computed as follows: 1) the change was calculated for each model simulation; 2) different runs using the same model (when available) were averaged; 3 ) the results were interpolated to a $1^{\circ}$ latitude/longitude spatial resolution; 4) the ensemble average over the different available models was obtained; and 5) the three emission scenarios were averaged.

\subsection{Regional climate change index}

The $R C C I$ is a qualitative index proposed by Giorgi (2006) to identify the regions in which climate change may be more prominent. This index is based on the temperature change in a specific region relative to the change in mean global temperature (or regional warming amplification factor, $R W A F)$, change in mean regional precipitation $(\triangle P, \%)$ and change in the interannual variability of temperature $\left(\Delta \sigma_{T}, \%\right)$ and precipitation $\left(\Delta \sigma_{P}, \%\right)$, all of which are calculated separately for austral summer and winter. The $R C C I$ is not affected by small changes below certain thresholds, while more intense changes receive heavier weights (Giorgi 2006).

In the $R C C I$ formulation, the $\sigma_{T}$ and $\sigma_{P}$ indexes can represent a proxy for extreme climate conditions, such as excessively rainy or dry seasons, that could seriously affect human welfare and the environment. The interannual standard deviation of temperature was used as a measure of $\sigma_{T}$, and the coefficient of variation (i.e., the standard deviation divided by the mean) was used as a measure of $\sigma_{P}$. Both $\sigma_{T}$ and $\sigma_{P}$ were calculated for the selected 30 year periods after detrending the data to obtain unbiased variability estimates. The coefficient of variation was used as a measure of interannual precipitation variability because it removes the dependency of the standard deviation on the mean for zero-bounded variables such as rainfall (Räisänen 2002; Giorgi 2006).

However, it is worth mentioning that the process of estimating the occurrence of extreme events is non-trivial, especially for projections of the future climate (Frich et al. 2002; Meehl et al. 2005; Tebaldi et al. 2006 and citations quoted therein). The interannual variability calculated using the standard deviation and coefficient of variation are used only as a first approximation for such events (Räisänen 2002; Giorgi 2006 and $\mathrm{Xu}$ et al. 2009). A more suitable extreme climate calculation could be derived, for example, from a robust statistical estimate of the probability density function of daily temperature and precipitation data (Alexander et al. 2006) generated by an ensemble of higher-resolution models.

The $R C C I$ was chosen for this study because it is a well accepted index in the literature to show where climate change could be, on a relative basis, more pronounced in a warmer climate based in a large set of climate models. Moreover, its results compare quite well with another well accepted index, the Climate Change Index, developed by Baettig et al. (2007), as will be discussed in Section 3.1. 


\subsection{Socio-climatic vulnerability index}

This paper introduces an index that combines information about the magnitude of climate change in a specific region and social factors that could affect the vulnerability of the local population. We call this index the Socio-Climatic Vulnerability Index (SCVI) and define it as

$$
S C V I=C I * \sqrt[n]{\prod_{i=1}^{n} F_{i}},
$$

where $C I$ represents any climate change index suitable for the region, whereas the second element on the right-hand side of the equation represents the geometric mean of the normalized social vulnerability factors $\left(F_{i}\right)$ that characterize the local social conditions.

The definition of vulnerability used here is based on that used by the IPCC: vulnerability is the degree to which a system (in this study, the Brazilian population) is susceptible to, and unable to cope with, adverse effects of climate change, including climate variability and extremes. Additionally, vulnerability is a function of the character, magnitude, and rate of climate change and the variation to which a system is exposed, its sensitivity and its adaptive capacity (glossary of IPCC AR4, [IPCC 2007]).

Similar to the RCCI, the $S C V I$ is intended to be a relative index of vulnerability to climate change in which the most important is not the value itself, but how it compares from one region to another, ranking locations in which vulnerability is high or low in a comparative basis. Moreover, the SCVI can be applied on any spatial scale (assuming sufficient available data and a reasonable spatial scale for characterizing the analyzed region) and can incorporate as many distinct social variables as needed in the right-hand side of the equation above. Therefore, the $S C V I$ can merge several indicators of a population's vulnerability (e.g., water resources and agricultural vulnerabilities) and climate change indexes based on a broad array of models.

The specialized literature includes dozens of indexes for indentifying a population's vulnerability to climate change on a country (e.g., Yohe et al. 2006; Diffenbaugh et al. 2007; Eriksen and Kelly 2007) or regional scale (e.g., Confalonieri et al. 2009 and Yusuf and Francisco 2009). For example, Preston et al. (2011) identified and reviewed 45 vulnerability mapping studies appearing in the literature until 2010. These studies differ from the present study in the following ways: several of the previous studies used observed climatology rather than climate change projections, nearly all of the previous studies were based on climate projections from solely one climate model and Brazil was always depicted using coarse spatial scales.

The SCVI was calculated for all of Brazil using a spatial resolution of $1^{\circ}$ of latitude/ longitude. The climate change index used here is the $R C C I$ described in the previous section, but the use of other climate change indexes in addition to or instead of the RCCI could strengthen the reliability of the determination of climate change hotspots. The demographic density $(\rho)$ (Goldewijk 2005) and the inverse of the Human Development Index (HDI) for all Brazilian municipalities (IPEA 2003) are used as the social vulnerability indicators (Fig. 1). Both social variables are normalized to the Brazilian domain and are representative of the year 2000. The original resolution of $\rho$ is 5 arc-minutes, whereas the HDI data are available at the municipal level. The transformation of these data to a $1^{\circ}$ basis followed the procedures using the ArcGIS ${ }^{\circledR}$ software: first, the $H D I$ data are transformed from a polygon shape into a 5 arc-min raster; second, both $H D I$ and $\rho$ are converted into $1^{\circ}$ latitude/longitude rasters using the "mean" neighborhood block statistics.

The employed SCVI formulation implies that the social vulnerability to climate change will be more pronounced in regions with higher $\rho$ and lower HDI, in agreement with several studies on social vulnerability to climate change (Adger 1999; Füssel and Klein 2006; 
a

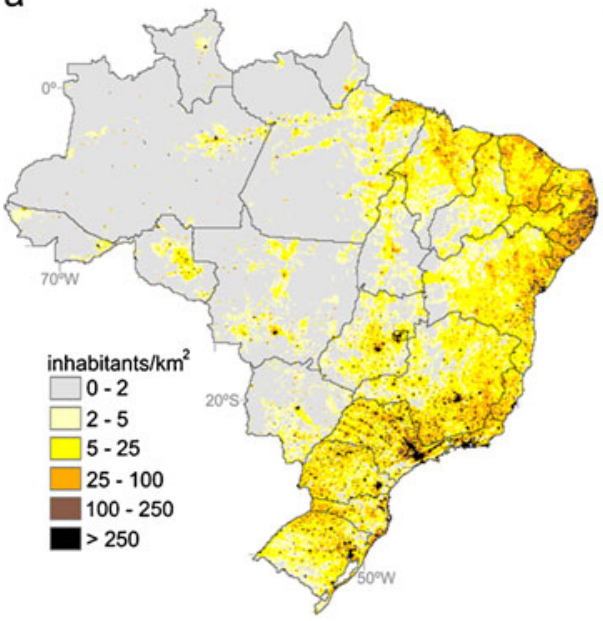

b

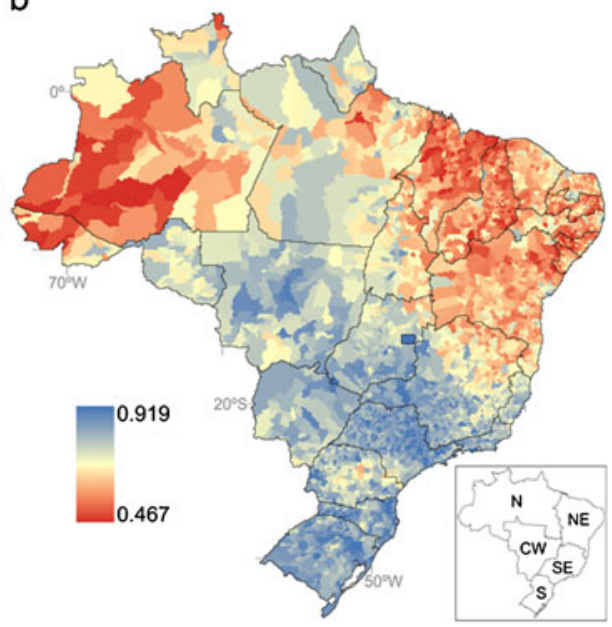

Fig. 1 Year 2000 (a) Brazilian population density (inhabitants per $\mathrm{km}^{2}$ ) and (b) Human Development Index (dimensionless). The bottom right-hand panel shows Brazil's 5 macro regions: North (N), Northeast (NE), Centre-West (CW), South (S) and Southeast (SE)

Eriksen and Kelly 2007; Magrin et al. 2007; Ionescu et al. 2009; Confalonieri et al. 2009). In general, these studies agree that social vulnerability is more pronounced in more heavily populated areas (justifying the use of $\rho$ ), and that sanitation/health, economic wealth and literacy levels influence exposure and sensitivity to climate change, and modulate the population's adaptive capacity for climate change. The HDI conveniently combines these three social indicators - health, income and education - into a single measure.

The most recent HDI information at the municipality level for Brazil was published in 2000 by the Brazilian office of the United Nations Development Programme in conjunction with the Ministry of Planning's Applied Economic Research Institute (IPEA) and the João Pinheiro Foundation (http://hdr.undp.org/en/reports/national/latinamericathecaribbean/ brazil/name,3212, en.html). Unfortunately, more recent information at this level of detail is not available for either HDI or population density. However, although the values of $H D I$ have changed from 2000 to 2011 (e.g., from 0.665 to 0.718 on the national level), it is reasonable to assume that the broad regional development patterns have not changed considerably. We assume the same for population density in terms of 2000-2011 changes in the spatial distribution pattern.

\section{Results and discussion}

\section{$3.1 R C C I$}

The analysis of the RCCI for Brazil (Fig. 2a) evidences the occurrence of climatic hotspots covering the western part of the NE region, the northwestern part of Minas Gerais state and the center-west $(\mathrm{CW})$ and northern $(\mathrm{N})$ regions of the country (except in northeast Pará and Amapá states).

In western NE and northwestern Minas Gerais state, the main factors that contribute to the higher values of the RCCI are the projected decrease of rainfall amounts during the austral 

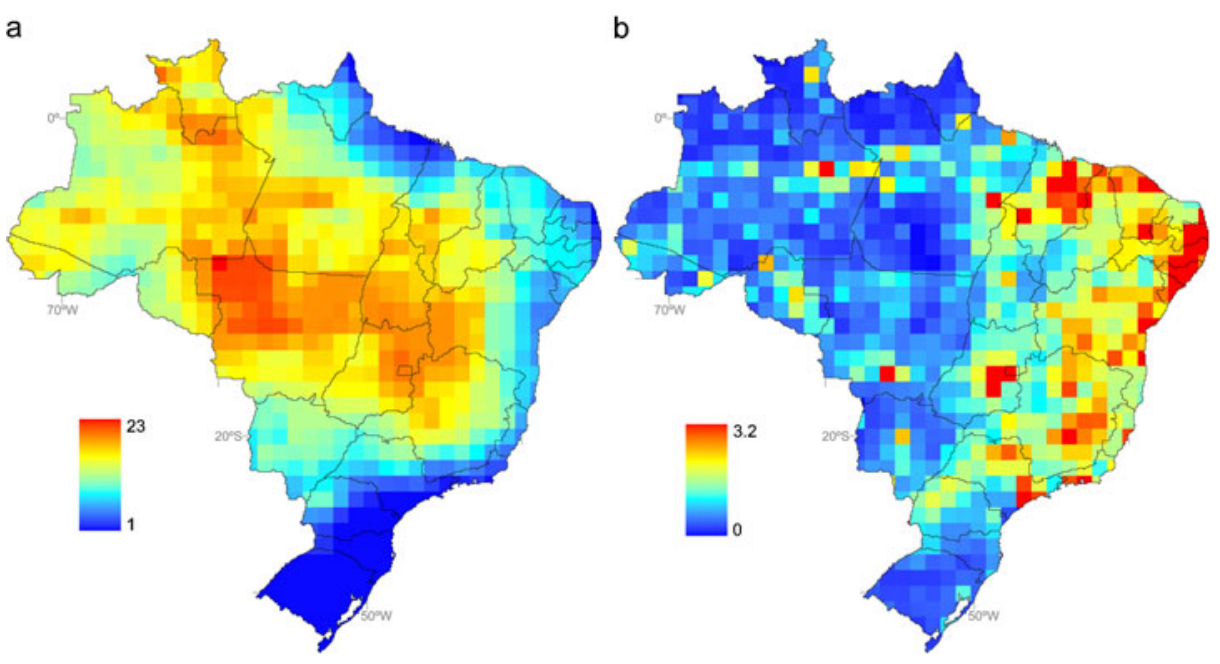

Fig. 2 (a) Regional Climate Change Index $(R C C I)$ and (b) Socio-Climatic Vulnerability Index $(S C V I)$ for Brazil (both dimensionless)

winter and changes in the interannual variability of temperature and precipitation in both seasons (Table 2). In the CW region, high values of the $R C C I$ are primarily caused by changes in both the mean and interannual precipitation variability in the austral winter and in the interannual temperature variability in the austral summer (Table 2). In $\mathrm{N}$ region the main contributors to high values of the $R C C I$ are the changes in the interannual temperature variability in both the austral summer and winter and the interannual variability of rainfall and the $R W A F$ during the austral winter (Table 2).

In general, the $R C C I$ results agree with previous studies that use regional and GCM models to project climate change in South America (Boulanger et al. 2006, 2010; Vera et al. 2006; IPCC 2007; Bombardi and Carvalho 2009; Marengo et al. 2010a, 2011a). Moreover, the spatial pattern of the $R C C I$ in Brazil compares well to the Climate Change Index

Table 2 Mean values for the 5 Brazilian macro regions (see Fig. 1 for geographic reference) of the Regional Climate Change Index $(R C C I)$ and its four components of climatic change: mean precipitation $(\triangle P, \%$ of present-day value), interannual variability of precipitation $\left(\Delta \sigma_{\mathrm{P}}, \%\right.$ of present-day value $)$, mean surface air temperature relative to the global average temperature change (or Regional Warming Amplification Factor, $R W A F)$ and change in regional surface air temperature interannual variability $\left(\Delta \sigma_{\mathrm{T}}, \%\right.$ of present-day value). Results are shown for the austral summer and winter (DJF and JJA, respectively), except for the $R C C I$

\begin{tabular}{|c|c|c|c|c|c|}
\hline & North & Northeast & Centre-West & Southeast & South \\
\hline RCCI & 15.99 & 13.01 & 17.71 & 12.86 & 4.81 \\
\hline$\Delta P(\mathrm{DJF})$ & 5.97 & 0.99 & 2.43 & 1.32 & 7.70 \\
\hline$\Delta P(\mathrm{JJA})$ & -5.82 & -17.45 & -18.01 & -13.11 & 4.48 \\
\hline$\Delta \sigma_{\mathrm{P}}(\mathrm{DJF})$ & 5.00 & 10.10 & 8.39 & 10.01 & 1.06 \\
\hline$\Delta \sigma_{\mathrm{P}}(\mathrm{JJA})$ & 17.35 & 14.74 & 26.42 & 17.20 & 10.06 \\
\hline$R W A F(\mathrm{DJF})$ & 1.14 & 1.04 & 1.10 & 1.02 & 0.92 \\
\hline$R W A F(\mathrm{JJA})$ & 1.48 & 1.15 & 1.44 & 1.23 & 1.06 \\
\hline$\Delta \sigma_{\mathrm{T}}(\mathrm{DJF})$ & 16.11 & 12.40 & 21.15 & 18.10 & 6.11 \\
\hline$\Delta \sigma_{\mathrm{T}}(\mathrm{JJA})$ & 16.73 & 12.67 & 13.73 & 9.55 & 3.23 \\
\hline
\end{tabular}


developed by Baettig et al. (2007), although the two indexes are calculated by different ensemble models and methodologies. Additionally, all areas indicated as hotspots by the $R C C I$ were also predicted to suffer soil moisture deficits and an increase in the frequency of short-term (4-6 month duration) droughts by the end of the twenty-first century by Sheffield and Wood (2008). In the Amazon basin, the RCCI results are coherent with the well documented potential of climate change to enhance intense drought events in this region, such as the droughts of 2005 and 2010 (Malhi et al. 2008; Nobre and Borma 2009; Lewis et al. 2011; Marengo et al. 2011b, c, d; Davidson et al. 2012), which caused serious hydrological, agricultural and transportation problems, strongly affecting residents.

The lowest values of the climate index were found for Southern Brazil (S), in the states of São Paulo and Mato Grosso do Sul, and throughout the Brazilian coast. However, these low $R C C I$ values should not be interpreted as indicating "no-change" or "no-impact" but rather as a smaller change relative to other regions of Brazil. For example, some studies indicate an increase in the frequency of extreme precipitation events in S during the last half of the twentieth century (e.g., Tebaldi et al. 2006; Rusticucci et al. 2010; Marengo et al. 2010b) and indicate a further increase in these events towards the end of the twenty-first century in a warmer climate (Tebaldi et al. 2006; Marengo et al. 2009). Thus, as mentioned in Section 2.2, future studies must improve the RCCI index calculation (i.e., using higher-resolution models and more advanced statistical techniques) to explicitly capture climate extreme events.

South America has the lowest $R C C I$ values among the 26 averaged land regions of the world analyzed by Giorgi (2006). However, our study reveals that different climate change patterns are found inside each of the 3 (out of 26) boxes established to represent the South America climate change behavior in Giorgi's study ["Amazon Basin" (20 S-10 N; 78.5-34.5 W), "Central South America" (40-20 S; 78.5-34.5 W) and "Southern South America" (56-40 S; 78.5-34.5 W)]. For example, the "Amazon Basin" box includes NE and Peru/Ecuador, regions with different predictions regarding precipitation change (Vera et al. 2006; Meehl et al. 2005). Differently, the results from the spatial analysis of the $R C C I$ performed here emphasize the different projected climate change pattern when comparing $\mathrm{N}$ and $\mathrm{NE}$ regions.

\section{$3.2 S C V I$}

The SCVI analysis reveals major socio-climatic hotspots in NE Brazil and several widespread punctual hotspots in many of the major Brazilian metropolitan regions (Fig. 2b). The spatial pattern of the $S C V I$ is quite different from that of the $R C C I$; it reveals an east-west gradient related to the historical occupation of the coastal lands and its vicinities in Brazil, which indicates that population density has a considerable weight in SCVI calculations. Therefore, the SCVI analysis shows that the designation of the most impacted areas by climate change can be quite different when translated into a social-vulnerability relevant form.

The large socio-climatic hotspots in NE result from a combination of low-to-medium $R C C I$ values, relatively high $\rho$, and the lowest $H D I$ levels in Brazil (Table 3). This result is in agreement with those shown of Confalonieri et al. (2009), who found that the NE region is the most vulnerable to public health impacts of climate change in Brazil, although those authors employed only past climatological observations in their analysis and presented their results on a state-level basis. However, the inclusion of the epidemiological vulnerability index presented by Confalonieri et al. (2009) in the SCVI calculation (making our results more comparable to those of Confalonieri et al.'s) did not change the relative socio-climatic vulnerability among the regions: NE remained as the most vulnerable area in the country, followed by SE, CW, S and $\mathrm{N}$. This epidemiological vulnerability index was constructed by Confalonieri et al. (2009) using morbidity, mortality and health cost data related to seven 
Table 3 Mean values for the 5 Brazilian macro regions (see Fig. 1 for geographic reference) of the Socio-Climatic Vulnerability Index (SCVI, dimensionless), Human Development Index (HDI, dimensionless) and population density $\left(p\right.$, inhabitants per $\left.\mathrm{km}^{2}\right)$

\begin{tabular}{llcccc}
\hline & North & Northeast & Centre-West & Southeast & South \\
\hline SCVI & 0.30 & 0.93 & 0.43 & 0.85 & 0.31 \\
HDI & 0.651 & 0.612 & 0.741 & 0.738 & 0.766 \\
$\rho$ & 3.82 & 33.48 & 7.52 & 80.45 & 45.18 \\
\hline
\end{tabular}

climate-sensitive endemic infectious diseases occurring in Brazil (e.g., dengue fever, cholera and malaria).

The other punctual socio-climatic hotspots covering some of the major Brazilian cities are Manaus (SCVI=3.2), Belo Horizonte (3.2), Brasília (3.1), Salvador (2.8), Rio de Janeiro (2.6) and São Paulo (1.7), as well as nearly all the NE capitals. Some of the values found for these cities are the result of high or very high RCCI values, as is the case for Manaus, Belo Horizonte and Brasília. For the other cities, even the relatively low $R C C I$ values are not sufficient to avoid the high $S C V I$ values, meaning that even a moderate climate change might bring serious consequences to these cities because of their high population densities. High $\rho$ values in Brazil indicate metropolitan areas, for which the SCVI formulation is able to correctly capture the effect of the pronounced social heterogeneity typical of the country's largest cities. As an example, let us consider the metropolitan area of São Paulo city, which in 2000 had an HDI of 0.828 , suggesting a high human development level. However, a finer-scale analysis reveals that the São Paulo metropolitan region has several districts (especially in the city outskirts) with HDI values lower than 0.750 , considered "moderate" human development, similar to many $\mathrm{N}$ and NE municipalities. A recent assessment of the overall vulnerability of the São Paulo metropolitan area to climate change shows that the residents of such districts would be affected most strongly by climate change through floods, landslides, and spreading diseases (Nobre et al. 2010). It is reasonable to apply the same conclusion to the other Brazilian metropolitan regions unveiled here as socio-climatic hotspots, as suggested by the neighborhood-level HDI analysis performed for other cities (e.g., SEPLAN et al. 2006 for Manaus; PNUD et al. 2006 for Salvador; IPP et al. 2003 for Rio de Janeiro).

In fact, the above-mentioned social impacts of climate change can vary dramatically by region and livelihood. For the NE, the major climatic constraint has always been linked to rainfall shortage and limited water availability for human consumption and subsistence agriculture (Kabat et al. 2003; Sahota 1968). The decomposition of the RCCI into separate components, given in Table 2, reveals that the future impacts of climate change on the NE population will be tied to aggravations of rainfall shortage and limited water availability. For metropolitan areas, these impacts will certainly be expressed by floods, landslides, heat waves, and possibly other events, which are closely linked to the urbanization pattern. It is important to note that some indirect impacts of climate change have not been included in this vulnerability assessment. Climate-driven agricultural losses can, for example, increase the vulnerability of a given population, even if the croplands are located in depopulated areas far from consuming centers. This issue is not addressed by this spatial analysis using only the $H D I$ and $\rho$ as social vulnerability indicators, and will be tackled in future studies.

Finally, low SCVI values should not be interpreted as "no action needed". The SCVI index must be used as an auxiliary index in climate change debates rather than a substitutive to other specific vulnerability or impact indexes, such as the $R C C I$. Although it is reasonable to focus adaptation policies on regions where more people are affected, some adaptation measures are needed to strengthen the adaptive capacity of less dense, but no less important, 
areas. Let us take as an example the Brazilian Legal Amazon population of 23 million people, which is scattered over an area of more than 5 million $\mathrm{km}^{2}$. If impacted by climate change, we may expect a south/eastward population migration, which would increase $\rho$ in already dense areas, thereby worsening the SCVI values in South/East Brazil, similar to the results of past dry spell events in Northeast Brazil (Yap 1976).

\subsection{Final remarks}

This study is a first-order spatially explicit evaluation of the social vulnerability to climate change in Brazil. Refinements should include the use of regional climate models (with spatial resolutions of $50 \mathrm{~km}$ or higher) or advanced statistical downscaling techniques and the consideration of other indicators of social vulnerability (such as fine-scale epidemiological information, data on susceptibility to landslides and floods, water availability, and agricultural risks).

That being said, the two major contributions of this study are the presentation of a more detailed analysis of the RCCI in Brazil (compared to the study by Giorgi 2006) and the development of a new index (SCVI) that merges the extensive number of IPCC global model projections on climate change with social vulnerability indicators. Moreover, this proposed index could be applied to other countries and regions. Both the RCCI and SCVI indexes have a simplistic and exploratory nature but can be useful for improving the dialogue between climate and social scientists and communicating climate change to policymakers in a more synthetic and socially relevant form.

Acknowledgments We are thankful to M. D. Oyama and C. A. Nobre for their helpful comments on the early drafts of this manuscript. Three anonymous reviewers provided suggestions that considerably improved the quality of the manuscript. The first author was supported by the Coordenação de Aperfeiçoamento de Pessoal de Nível Superior (CAPES) and by Brazil's Conselho Nacional de Desenvolvimento Científico e Tecnológico (CNPq). Additional support was provided by FAPESP through the "Assessment of impacts and vulnerability to climate change in Brazil and strategies for adaptation options" project (Proc. \# 2008/58161-1). We also thank the Program for Climate Model Diagnosis and Intercomparison (PCMDI) and the WCRP's Working Group on Coupled Modelling (WGCM) for making the CMIP3 multi-model dataset available.

\section{References}

Adger WN (1999) Social vulnerability to climate change and extremes in coastal Vietnam. World Develop 27:249-269

Alexander LV, Zhang X, Peterson TC, Caesar J, Gleason B, Tank AMGK, Haylock M, Collins D, Trewin B, Rahimzadeh F, Tagipour A, Kumar KR, Revadekar J, Griffiths G, Vincent L, Stephenson DB, Burn J, Aguilar E, Brunet M, Taylor M, New M, Zhai P, Rusticucci M, Vazquez-Aguirre JL (2006) Global observed changes in daily climate extremes of temperature and precipitation. J Geophys Res 111:D05109

SEPLAN (Secretaria de Estado Planejamento e Desenvolvimento Econômico do Amazonas), Prefeitura de Manaus, Programa das Nações Unidas para Desenvolvimento Brasil, Fundação João Pinheiro. 2006. Atlas do Desenvolvimento Humano em Manaus. Manaus, SEPLAN/Prefeitura de Manaus,/PNUD-Brasil/ Fundação João Pinheiro. 24p. Available at: http://www.pnud.org.br/publicacoes/atlas manaus/Release Atlas.pdf. Accessed in 01/Feb/2012

Baettig MB, Wild M, Imboden DM (2007) A climate change index: Where climate change may be most prominent in the 21st century. Geophys Res Lett 34:L01705

Bombardi RJ, Carvalho LMV (2009) IPCC Global coupled climate model simulations of the South America Monsoon System. Clim Dyn 33:893-916

Boulanger JP, Martinez F, Segura EC (2006) Projection of future climate change conditions using IPCC simulations, neural networks and Bayesian statistics. Part 1: temperature mean state and seasonal cycle in South America. Clim Dyn 27:233-259 
Boulanger JP, Brasseur G, Carril AF, Castro M, Degallier N, Ereño C, Le Treut H, Marengo JA, Menendez CG, Nuñez MN, Penalba OC, Rolla AL, Rusticucci M, Terra R (2010) A Europe-South America network for climate change assessment and impact studies. Clim Change 98:307-329

Christensen JH, Carter TR, Rummukainen M, Amanatidis G (2007) Evaluating the performance and utility of regional climate models: the PRUDENCE project. Clim Change 81:1-6

Confalonieri UEC, Marinho DP, Rodriguez RE (2009) Public health vulnerability to climate change in Brazil. Clim Res 40:175-186

Davidson EA, Araujo AC, Artaxo P, Balch JK, Brown IF, Bustamante MMC, Coel MT, DeFries RS, Keller M, Longo M, Munger JW, Schroeder W, Soares-Filho BS, Souza CM Jr, Wofsy SC (2012) The Amazon basin in transition. Nature 481:321-328

Folha de São Paulo (2010) Reféns da chuva. Folha de São Paulo, 22. Jan.2010, p. C1

Folha de São Paulo (2011) Estado do Rio enfrenta a pior chuva em mais de 4 décadas. Folha de São Paulo, 13. Jan.2011, p. A1

IPP (Instituto Municipal de Urbanismo Pereira Passos), Instituto Universitário de Pesquisas do Rio de Janeiro, Instituto de Pesquisa Economica Aplicada, Fundação João Pinheiro. 2003. IDH dos bairros do Rio de Janeiro. Available at: http://www.pnud.org.br/pdf/Tabela\%206.2.22\%20IDH\%20bairro\%2091_0015 12_03.xls, Accessed in 01/Feb/2012

PNUD (Programa das Nações Unidas para Desenvolvimento Brasil), Companhia de Desenvolvimento Urbano do Estado da Bahia, Fundação João Pinheiro, Instituto Brasileiro de Geografia e Estatística. 2006. Atlas de Desenvolvimento da Região Metropolitana de Salvador. PNUD/CONDER/Fundação João Pinheiro/ IBGE. Available at: http://www.pnud.org.br/publicacoes/atlas_salvador/index.php. Accessed in: 01/Feb/ 2012

Diffenbaugh NS, Giorgi F, Raymond L, Bi X (2007) Indicators of $21^{\text {st }}$ century socioclimatic exposure. Proc Natl Acad Sci USA 104:20195-20198

Eriksen SH, Kelly PM (2007) Developing credible vulnerability indicators for climate adaptation policy assessment. Mitig Adapt Strategies Glob Chang 12:495-524

Frich P, Alexander LV, Della-Marta P, Gleason B, Haylock M, Tank AMGK, Peterson T (2002) Observed coherent changes in climatic extremes during the second half of the twentieth century. Clim Res 19:193212

Füssel HM, Klein RJT (2006) Climate change vulnerability assessments: an evolution of conceptual thinking. Clim Change 75:301-329

Giorgi F (2005) Climate change prediction. Clim Change 73:239-265

Giorgi F (2006) Climate change hot-spots. Geophys Res Lett 33:L08707

Giorgi F, Bi XQ (2005) Updated regional precipitation and temperature changes for the $21^{\text {st }}$ century from ensembles of recent AOGCM simulations. Geophys Res Lett 32:L21715

Goldewijk KK (2005) Three centuries of global population growth: a spatial referenced population (density) database for 1700-2000. Popul Environ 26:343-367

IBGE (Brazilian Institute of Geography and Statistics) (2009) Censo agropecuário 2006. Primeiros resultados: Agricultura Familiar Brasil, grandes regiões e unidades da federação. Instituto Brasileiro de Geografia e Estatística Rep., 267pp. Available at: http://www.ibge.gov.br/home/estatistica/economia/agropecuaria/ censoagro/agri_familiar_2006/familia_censoagro2006.pdf

Ionescu C, Klein RJT, Hinkel J, Kumar KS $\overline{S K}$, Klein R (2009) Towards a formal framework of vulnerability to climate change. Environ Model Assess 14:1-16

IPCC (2007) Summary for policymakers. In: Solomon S, Qin D, Mamming M, Chen Z, Marquis M, Averyt KB, Tignor M, Miller HL (eds) Climate change 2007: the physical science basis. Contribution of Working Group I to the Fourth Assessment Report of the Intergovernmental Panel on Climate Change. Cambridge University Press, Cambridge, United Kingdom and New York, NY, USA

IPEA (Institute for Applied Economic Research) (2011) O comércio internacional e a sustentabilidade socioambiental no Brasil. Available at: http://www.ipea.gov.br/portal/images/stories/PDFs/comunicado/ 110222_comunicadoipea79.pdf, acess in 03.05.2011

IPEA (Institute for Applied Economic Research), United Nations Development Programme Brazil, Joao Pinheiro Foundation (2003) Atlas do Desenvolvimento Humano no Brasil. Available at: www.pnud.org.br/ atlas, access in 13.04.2011

Jones PW (1999) First- and second-order conservative remapping schemes for grids in spherical coordinates. Mon Wea Rev 127:2204-2210

Kabat P, van Schaik, Appleton B, Eds (2003) Climate changes the water rules: how water managers can cope with today's climate variability and tomorrow's climate change. Dialogue on Water and Climate, NL, $106 \mathrm{p}$

Knutti R (2008) Should we believe model predictions of future climate change? Phil Trans R Soc 366:46474664 
Lewis SL, Brando PM, Phillips OL, Geertje MF, van der Heijden ND (2011) The 2010 Amazon drought. Science 331:554

Lucena AFP, Szklo AS, Schaeffer R, Souza RR, Borba BSMC, Costa IVL, Pereira Júnior AO, Cunha SHF (2009) The vulnerability of renewable energy to climate change in Brazil. Energy Policy 37:879-889

Magrin G, Gay García C, Cruz Choque D, Giménez JC, Moreno AR, Nagy GJ, Nobre C, Villamizar A (2007) Latin America. Climate Change 2007: Impacts, Adaptation and Vulnerability. Contribution of Working Group II to the Fourth Assessment Report of the Intergovernmental Panel on Climate Change, Parry ML, Canziani OF, Palutikof JP, van der Linden PJ, Hanson CE, Eds., Cambridge University Press, Cambridge, UK, 581-615

Malhi Y, Roberts JT, Betts RA, Killeen TJ, Li W, Nobre CA (2008) Climate change, deforestation and the fate of the Amazon. Science 319:169-172

Marengo JA, Jones R, Alves L, Valverde M (2009) Future change of temperature and precipitation extremes in South America as derived from the PRECIS regional climate modeling system. Int J Climatol 29:2241-2255

Marengo JA, Ambrizzi T, Rocha RP, Alves LM, Cuadra SV, Valverde M, Ferraz SET, Torres RR, Santos DC (2010a) Future change of climate in South America in the late XXI century: intercomparison of scenarios from three regional climate models. Clim Dyn 35:1073-1097

Marengo JA, Rusticucci M, Penalba O, Renom M (2010b) An intercomparison of observed and simulated extreme rainfall and temperature events during the last half of the twentieth century. Part 2: historical trends. Clim Change 98:509-529

Marengo JA, Chou SC, Kay G, Alves LM, Pesquero JF, Soares WR, Santos DC, Lyra AA, Sueiro G, Betts R, Chagas DJ, Gomes JL, Bustamante JF, Tavares P (2011a) Development of regional future climate change scenarios in South America using the Eta CPTEC/HadCM3 climate change projections: climatology and regional analyses for the Amazon, São Francisco and the Parana River Basins. Clim Dyn: on line first

Marengo JA, Nobre CA, Chou SH, Tomasella J, Sampaio G, Alves LM, Obregón GO, Soares WR, Betts R, Kay G (2011b) Dangerous Climate Change. A Brazil-UK analysis of climate change and deforestation impacts in the Amazon. 55pp. Available at: http://mudancasclimaticas.cptec.inpe.br/ rmclima/pdfs/destaques/ relatorio_ingl.pdf

Marengo JA, Tomasella J, Alves LM, Soares W, Rodriguez DA (2011c) The drought of 2010 in the context of historical droughts in the Amazon region. Geophys Res Lett 38:L12703

Marengo JA, Tomasella J, Soares W, Alves LM, Nobre C (2011d) Extreme climatic events in the Amazon basin: climatological and hydrological context of recent floods. Theor Appl Climatol 107:73-85

Meehl GA, Arblaster JM, Tebaldi C (2005) Understanding future patterns of increased precipitation intensity in climate model simulations. Geophys Res Lett 32:L18719

Meehl GA, Covey C, Delworth T, Mojib L, McAvaney B, Mitchell JFB, Stouffer RJ, Taylor KE (2007) The WCRP CMIP3 multimodel dataset: a new era in climate change research. Bull Am Meteorol Soc $88: 1383-1394$

Nakicenovic N, Alcamo J, Davis G, De Vries B, Fenhann J, Gaffin S, Gregory K, Grubler A, Jung TY, Kram T, La Rovere EL, Michaelis L, Mori S, Morita T, Pepper W, Pitcher H, Price L, Riahi K, Roehrl A, Rogner HH, Sankovski A, Schlesinger M, Shukla P, Smith S, Swart R, Van Rooijen S, Victor N, Dadi Z (2000) Special report on emissions scenarios. Cambridge University Press, UK

Nobre CA, Borma LS (2009) 'Tipping points' for the Amazon forest. Curr Opin Environ Sustain 1:28-36

Nobre CA, Young AF, Saldiva P, Marengo JA, Nobre AD, Alves Júnior SP, Silva GCM, Lombardo M (2010) Vulnerabilidades das megacidades brasileiras às mudanças climáticas: região metropolitana de São Paulo. Availabe at: http://www.inpe.br/noticias/arquivos/pdf/megacidades.pdf, access in 04.05.2011

Pidgeon N, Fischhoff B (2011) The role of social and decision sciences in communicating uncertain climate risks. Nature Clim Change 1:35-41

Ponce VM (1995) Management of droughts and floods in the semiarid Brazilian Northeast - the case for conservation. J Soil Water Conservat 50:422-431

Preston BL, Yuen EJ, Westaway RM (2011) Putting vulnerability to climate change on the map: a review of approaches, benefits, and risks. Sustain Sci 6:177-202

Räisänen J (2002) $\mathrm{CO}_{2}$-induced changes in interannual temperature and precipitation variability in 19 CMIP2 experiments. J Clim 15:2395-2411

Rusticucci M, Marengo JA, Penalba O, Renom M (2010) An intercomparison of observed and simulated extreme rainfall and temperature events during the last half of the twentieth century: Part 1: mean values and variability. Clim Change 98:493-508

Sahota GS (1968) An economic analysis of internal migration in Brazil. J Polit Econ 2:218-245

Sheffield J, Wood EF (2008) Projected changes in drought occurrence under future global warming from multi-model, multi-scenario, IPCC AR4 simulations. Clim Dyn 31:79-105

Tebaldi C, Hayhoe K, Arblaster JM, Meehl G (2006) Going to the extremes. An intercomparison of modelsimulated historical and future changes in extreme events. Clim Change 79:185-211 
Vera C, Silvestri G, Liebmann B, González P (2006) Climate change scenarios for seasonal precipitation in South America from IPCC-AR4 models. Geophys Res Lett 33:L13707

Xu Y, Xuejie G, Giorgi F (2009) Regional variability of climate change hot-spots in East Asia. Adv Atmos Sci 26(4):783-792

Yap L (1976) Internal migration and economic development in Brazil. Q J Econ 90(1):119-137

Yohe G, Malone E, Brenkert A, Schlesinger M, Meij H, Xing X (2006) Global distributions of vulnerability to climate change. Integ Assess J 6:35-44

Yusuf AA, Francisco H (2009) Climate change vulnerability mapping for Southeast Asia. Economy and Environment Program for Southeast Asia, Singapore 